\title{
Crackdown on Corruption: A Natural Experiment in Safe and Swing Districts
}

\author{
Bledi Celiku*
}

November 25, 2013

\begin{abstract}
I investigate the theoretical and empirical effects of increased law enforcement on the equilibrium level of bribes for the case of Albania during the period of 2005-2010. My paper centers on "harassment" bribes, which consist of payments for public services that by law should be free. I model bribery behavior as a negotiation process between public officials and consumers. As enforcement increases, corruption prevalence can, in theory, increase or decrease. Recent policy changes in Albania offer a good natural experiment to test this empirically. Two events took place in 2007: local elections and an increase in fines against corruption. I examine how the 2007 fine increase for corrupt behavior impacts bribery. Data show that corruption is a bigger problem for poor people and since the left's political platform is more pro-poor, looking at the left-right governed district variation seems appropriate. Using a difference in difference methodology that compares safe left and right-governed districts, I find that a 10 percent increase in enforcement leads to a 4.38 percent drop in bribery frequency. As enforcement increases, quality of services does not improve and enforcement measures are less effective on the medical and education sectors.
\end{abstract}

Key Words: Corruption, Public Servants, Bribery, Government JEL Codes: D73, K42, O12, P20

\footnotetext{
*I am grateful to my advisor William Jack for his guidance and support. I also appreciate the valuable comments of Arik Levinson and Martin Ravallion (committee members). I want to thank the Institute for Development Research and Alternatives (IDRA) for being collaborative and giving me access to the data. I acknowledge Mauricio Villamizar, Ergys Islamaj, Genta Menkulasi and seminar participants at the 2013 Midwest Economics Association and 2013 Georgetown Center for Economic Research Conference. All errors are my own. Email: bc253@georgetown.edu
} 


\section{Introduction}

This paper models bribery between consumers and public officials. I investigate both the theoretical and empirical effects of increased enforcement on bribe occurrence. Consumers need high quality public services to be delivered in a timely manner. However, public officials do not always deliver. When faced with added bureaucracy or explicit bribe requests, consumers face the dilemma of paying a bribe or assuming the risk of not getting the service at all. Similarly, public officials decide whether to supply services for free or to ask for bribes in order to expedite the process. In other words, officials implicitly value whether taking a bribe is worth more than the risk of getting caught. Depending on different combinations of increased enforcement i.e. fine increase or probability of getting caught, paired with quality of services changes, the share of population that engages in bribery theoretically can increase or decrease. In my empirical application I test the effect of increased enforcement on bribery. Corruption is a bigger problem for poor people, and since the left political platform is more pro-poor, looking at the left-right governed district variation is reasonable. I find that enforcement increases more in left-governed safe districts than in right-governed districts. Bribery occurrence decreases more in left-governed districts. In addition, by looking at sectoral variation, I find that the fine increase has a greater effect in non-medical and education sectors than in other sectors like judicial, billing, document processing sectors. One possible explanation is that maintaining a relationship with your doctor or teacher is more of a repetitive game as compared to getting a certificate or passport which is a one period game.

While there have been many different opinions regarding the effects of corruption on the economy, scholars have mostly agreed that corruption in developing countries is costly (Olken and Pande 2011). As corruption is illegal and hard data on corrupt transactions are hard to find, measuring corruption is difficult. However, since the birth of the corruption literature dating back to studies such as Becker and Stigler (1974) and Rose-Ackerman (1978), significant progress has been achieved. Several corruption perceptions indices exist today like the Corruption Perception Index (CPI) and the World Bank Governance Indicator. They publish yearly indices on corruption perceptions for every country, hence providing a basis for comparison. Nevertheless, "Corruption is a complex notion to be quantified in a single index" (Thompson and Shah 2005). Finding good instruments for corruption presents difficulties in a broad macroeconomic setting as endogeneity problems arise. Recently, researchers have put a lot of effort to collect more direct data on corruption, and a number of studies explain within-country corruption. Economists are finding innovative ways to measure corruption and its impact on the economy (examples include McMillan and Zoido (2004) and Reinikka and Svensson (2004)).

Most of the studies taking up enforcement and corruption have either been theoretical (Polinsky and Shavell 2001), or they have focused on a specific type of corruption (Fisman and Miguel 2007). 
Very few studies look at this issue empirically or study variation of enforcement effectiveness on corruption. The study investigates the effect of increased law enforcement on the equilibrium level of bribes ${ }^{1}$ during the 2005-2010 period in Albania (IDRA 2010). Since there are different underlying models of incentives for different types of bribery, this paper discusses "harassment" bribes only as defined in Basu (2011). It consists of bribes paid to public officials by consumers who demand services that they are legally entitled to, such as hospital treatment, passport or certificates issuance, school grade certificates or even court services.

By 2005, in Albania the incumbent Socialist Party (SP) had governed for 8 years and lost the general elections. The opposition ran under the slogan "With Clean Hands" and vowed to fight corruption when they came in power. Several reforms were instituted ranging from adapting anti-corruption laws to international standards, setting up new institutions like the "High Inspectorate for Declaration and Audit of assets" and "Joint Unit for the Investigation of Economic Crime and Corruption". Also measures like setting up e-procurement, e-taxation, and "one-stop shop" procedures to reduce contact with public officials were undertaken in this period. Albania's percentile ranking among several indicators published by the World Bank improved drastically during this period. As Figure 1 shows, it has drastically moved from being in the 20th percentile in 2005 to almost the 40th percentile in 2010 in the following categories: Government Effectiveness, Regulatory Quality, Rule of Law and Control of Corruption.

This paper proposes a victimization index measuring the several ways in which people could be victimized in paying bribes and test the effect of increased enforcement on victimization. Proxies for enforcement are based on variables such as the respondents' knowledge of judges being sanctioned and their awareness of anti-corruption initiatives. Estimating the causal effect of enforcement on bribery frequency is challenging because of the endogeneity problems involved. Omitted variables are an issue and other factors may have changed during this period that affected enforcement as well as victimization. For instance, the need for increased budget revenue or technological improvements might have also contributed in reducing the level of corruption. In order to account for endogeneity, the paper exploits two main changes that occurred in 2007. There was a federal fine increase in one of the anti-corruption laws in February and local elections that were held in May. I instrument enforcement with the interaction ${ }^{2}$ of the post treatment dummy with left-governed safe districts before and after elections. The exclusion restriction implied by the instrumental variable is that, the fine increase has no effect on Victimization, other than through enforcement. This is a plausible assumption, hence the validity of the IV is not threatened.

My findings suggest that an increase of enforcement of 10 percent leads to a 4.38 percent drop of bribery frequency. In theory, quality of services can shift either way when enforcement goes

\footnotetext{
${ }^{1}$ Data are taken from the "Corruption in Albania, Perception and Experiences" study.

${ }^{2}$ The interaction term is a difference-in-difference type of estimator.
} 
Figure 1: Albania's Governance Ranking

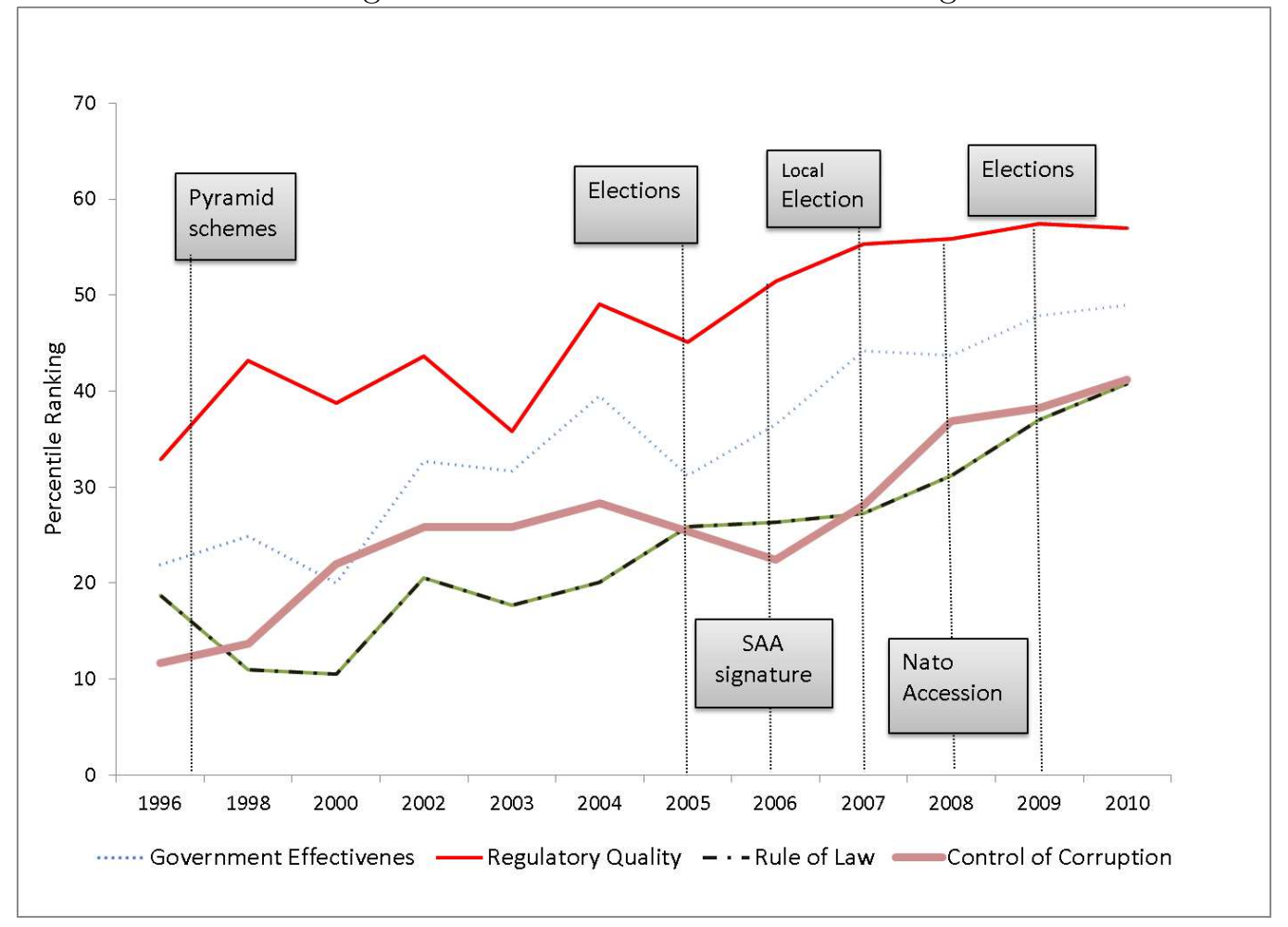

up but I show empirically that quality of services slightly decreases as enforcement increases. A difference-in-difference approach is used to show that the effect of the fine increase on the other sectors is significantly greater than on the medical sector and education sector grouped together. This results from cultural attributes in which people perceive transactions in these sectors as gift exchange out of gratitude or to nourish a long term relationship. Thus in theory the fine increase should not have any effect on these two sectors.

\section{Theoretical Framework}

A simple theoretical model will provide some context and help motivate the empirical work. into which factors can play a role in bribery incidence theoretically. The model is based on the seminal work by Becker and Stigler (1974) while some notation follow from Polinsky and Shavell (2001). The focus of the study is on harassment bribes paid by consumers for public service delivery. There are sanctions in place against such bribes which can be used against the briber or bribe taker. In the presence of such fines, consumers choose whether to bribe or not whereas the official chooses whether or not to accept the bribe. Since there exists a range of values for the parameters where paying a bribe is beneficial to both sides, bargaining occurs. There is heterogeneity across both sides of the market being represented by an idiosyncratic shock to their probability of getting caught. 
Consumers meet public officials randomly. These parameters define the share of population that engages in a bribe once they were matched. If the pair of random variables lies in the acceptable range (mutually beneficial), a bribe takes place, if not then one of the sides refuses to give/take a bribe.

Consider the willingness of a public sector official (doctor, judge or administrator) and a consumer to enter into a bribe agreement. Let $F$ be the fine ${ }^{3}$ imposed on the consumer in case he is caught bribing; $f$ be the fine imposed on the official in case he is found guilty and $b$ be the bribe payment to an official. Let's also define $\mu_{j}=\mu_{0}+\eta_{j}$ the probability of public official $j$ to get caught and $\rho_{i}=\rho_{0}+\epsilon_{i}$, the probability of consumer $i$ to get caught. Here $\mu_{0}$ and $\rho_{0}$ represent the mean probability of getting caught (presumably low if corruption is a problem) of the public officials and consumers whereas $\eta_{j}$ and $\epsilon_{i}$ represent intrinsic characteristics of each specific bribe case due maybe to a specific sector, the ability of the public official to hide his actions or the consumer's satisfaction with the service after bribing.

\subsection{Public Official's Decision}

Consider a public official who is willing to accept a bribe $b$ if the bribe is higher than his expected value of punishment $b>\mu_{j} f$. When he receives a bribe to provide the service, the official has an expected gain of:

$$
b-\mu_{j} f
$$

When he doesn't receive a bribe he provides the service for free and gets a zero expected payoff.

\subsection{Consumer Decision}

Now consider the decision of the consumer. If he pays a bribe $b$, he gets a gain $g$ from getting a better quality or faster service, but he faces an expected cost of $\rho_{i} F$ where the probability of getting caught is $\rho_{i}$ and $F$ is the fine. Accordingly, if the consumer pays the bribe he gets an expected payoff of:

$$
g-\rho_{i} F-b
$$

In case the consumer doesn't pay a bribe his expected payoff is $g^{\prime}$ which is lower than $g$ and represents the gain of not paying the bribe and waiting in line, getting the lower quality service or maybe not getting the service at all. Assuming risk neutrality and combining both cases, the consumer will be willing to bribe if and only if:

$$
g-\rho_{i} F-b>g^{\prime}
$$

\footnotetext{
${ }^{3}$ For simplicity it is assumed to be financial fines. It is not necessary for the model results, as imprisonment could be considered as well.
} 


\subsection{Equilibrium Bribe}

The public official is willing to accept a bribe $b$ if the bribe is higher than his expected value of punishment, so if $b>\mu_{j} f$ the consumer is willing to bribe if $b<g-\rho_{i} F-g^{\prime}$ from equation 2.3. As a result, there exists a range of bribes that are mutually beneficial if:

$$
\mu_{j} f<b<g-\rho_{i} F-g^{\prime}
$$

From 2.4 it follows that the surplus from entering into a bribe agreement is: $g-\rho_{i} F-g^{\prime}-\mu_{j} f$. It is positive when equation 2.4 holds. Assume that the bribe amount is such that the surplus from entering into the bribe arrangement will be split between the parties according to their bargaining power. Let $\phi$ be the bargaining power of the public official, where $0<\phi<1$. Then, the bribe amount is the solution to this Nash bargaining problem:

$$
\begin{aligned}
b & =\operatorname{argmax}\left(b-\mu_{j} f\right)^{\phi}\left(g-g^{\prime}-\rho_{i} F-b\right)^{1-\phi} \\
& =\mu_{j} f+\phi\left(g-g^{\prime}-\rho_{i} F-\mu_{j} f\right)
\end{aligned}
$$

The public official needs to be compensated at least $\mu_{j} f$ so that he is indifferent to the Nash agreement. Additionally he will get a proportion $\phi$ of the Nash bargaining split. Let the critical value of gain $(\hat{g})$ be the level of the gain below which a bribe agreement does not take place. By combining both sides of the market, using equation 2.3 and substituting $\mathrm{b}$ from equation 2.6 the following is true:

$$
\hat{g}=g^{\prime}+\mu_{j} f+\rho_{i} F
$$

\section{$3 \quad$ Testable Implications}

In order to understand equation 2.6 better, the following application might be useful. Assume that $\mu_{j}$ and $\rho_{i}$ are uniformly distributed. Figure 2 presents equation 2.3 graphically . The axes represent $\mu_{j}$ and $\rho_{i}$, the probability of getting caught for the public official and consumer respectively. The line represents:

$$
g-g^{\prime}=\mu_{j} f+\rho_{i} F
$$

Its slope is $-f / F$. If a consumer and a public official combined characteristics lie in the acceptance region, a bribe takes place. Otherwise, one side or both parties denies the transaction and the arrangement does not occur. The Appendix contains a comparative statics exercise where the penalty falls only on the public official or consumer respectively ${ }^{4}$

\footnotetext{
${ }^{4}$ In Basu (2011), the author claims letting the briber go free and only punishing the public official would result in bribery incidence going down. I investigate this issue in the model and in one of the four possible cases, shifting the
} 
Figure 2: Set of Combinations where Bribes take Place

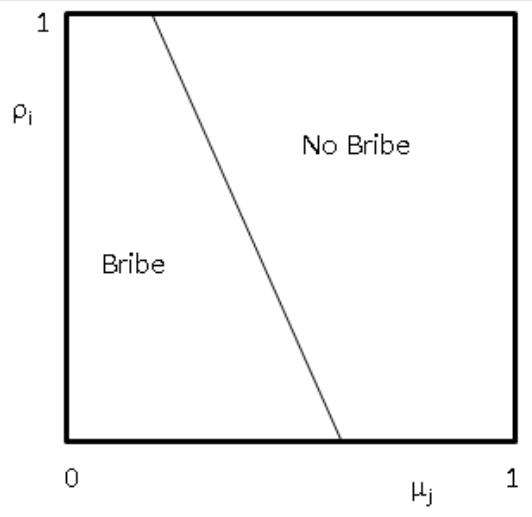

Consider the policy variables to be: $\mu_{0}, \rho_{0}, f$ and $F$. Under this setting a policy change (increase in law enforcement) can be represented in two scenarios: either a line shift in the box or a box shift. A box shift happens when $\mu_{0}$ and $\rho_{0}$ increase. The size of the box doesn't change, but the average probability of getting caught for the public official and/or consumer increases on average as more law enforcement is instituted. The new setting needs to be represented in a different box. Rearranging terms from equation 3.1 , the line equation becomes:

$$
\rho_{i}=\frac{g-g^{\prime}}{F}-\frac{f}{F} \mu_{j}
$$

A line shift can happen in case the intercept goes down and the slope stays the same (for the shift to be parallel). This means that $\left(g-g^{\prime}\right)$ has to decrease and both fine amounts have to change by the same amount so that the slope doesn't change. To simplify, substitute $\rho_{i}$ and $\mu_{j}$ in equation 3.2 and get:

$$
\epsilon_{i}=\frac{g-g^{\prime}-\rho_{0} F-\mu_{0} f}{F}-\frac{f}{F} \eta_{j}
$$

where $\epsilon_{i} \sim \mathcal{U}(0,1)$ and $\eta_{j} \sim \mathcal{U}(0,1)$.It is now simplified to be only a line shift or change in the same box and is shown in Figure 3 .

The factors that can decrease bribery ${ }^{5}$ are the following:

- Decrease in the quality of the bribed service $(g)$.

- Increase in the quality of the "free" service $\left(g^{\prime}\right)$.

- Increase in the probability of getting caught for the consumer $\left(\rho_{0}\right)$ and for the public official $\left(\mu_{0}\right)$.

blame to the officials only reduces bribery; in line with Basu (2011). In another case blaming only the consumer has the same decreasing effect on bribery. In two other cases results are ambiguous.

${ }^{5}$ Graphically this is defined as the area of the acceptance region or share of population that pays a bribe 
Figure 3: Increase in Law Enforcement

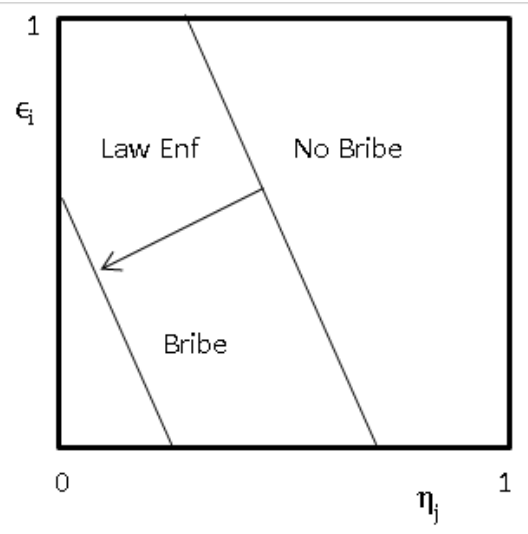

If the change occurs without slope changes, fines have to remain unchanged or they have to change by the same amount. In case there is a change on either the fine $F$ on the consumer side or fine $f$ on the public official side what happens to the acceptance region is unclear and could lead to different results $^{6}$. In addition, a fine increase paired with change in quality of "free" or bribed services can lead to an ambiguous result too. Summarizing, an increase in enforcement can lead to different results in bribery depending on the combination of effects noted above. This model provides some context into the actors that can influence bribery and how theoretically enforcement could change this. As it happened during this period in Albania, which I will show in the next sections, there is a fine increase on the public official side. I look at this question empirically and attempt to answer an issue which provides inconclusive results theoretically.

\section{Data}

The dataset in this paper consists of five consecutive repeated cross-section surveys designed and implemented for the "Corruption in Albania, Perception and Experiences in Albania" series from 2005 to 2010. ${ }^{7}$. Each survey has three components: 1) General Public sample 2) Public Sector Employees sample and 3) Judges' sample. The general public sample consists roughly of 1200 people surveyed each year. The public sector sample is comprised of 600 public officials surveyed each year. The judges' survey consists of a sample of roughly 200-300 judges surveyed in the period 2008-2010.

The general public sample was created based on a multi-stage random probability sampling drawn

\footnotetext{
${ }^{6}$ This can be verified by taking the derivative on the four possible areas of bribe acceptance region with respect to each fine in the appendix. Number four is the ambiguous one.

${ }^{7}$ It started as part of LAPOP studies (Latin America Public Opinion Polling)at Vanderbilt University. More information available at:http://vanderbilt.edu/lapop/index.php
} 
from a list of polling stations. Polling stations are the primary sampling unit in the design. Within the area designated by the polling station, respondents are selected based on random route sampling. Table 1 presents the summary statistics. Average age across years is around 42. The number of women surveyed is slightly higher than men, which correspond to total population demographics. Income data is collected by asking respondents in which bracket their family income falls. The income variable ranges from $[0,10]$ and in monetary value from $[0,300.000]$ Lek $^{8}$ per month. Since a value of income equal to three and four correspond to the range [15.000, 20.000] and [20.000, 50.000] Lek respectively, then an average income of 3.43 in 2005, corresponds to a value higher than 200 USD but lower than 500 USD. In order to make sure that income distribution in this survey is representative of Albania and does not show unusual features, I compare in the Appendix the monthly household income of this survey to the well known Living Standards Measurement Survey (LSMS) for Albania ${ }^{9}$. The comparison is done for year 2005 and results are pretty close to each other for both surveys. Ideology refers to a $[1,10]$ discrete scale where going from 1 to 10 peoples' beliefs move from far left to far right. On average people slightly favor more the right and the Democratic Party (DP), which is the political party in power centrally during the time of data collection. Education level data and occupation data are presented next ${ }^{10}$. Almost half of the sampled people have at most a High School education and 15-20 percent hold a University degree. Worth noting is that only 20-25 percent of the respondents are full time employed and almost the same share are unemployed which is slightly higher compared to the official data released by the World Bank ${ }^{11}$. This should not be perceived as sample bias as discrepancies can come from the way unemployment is measured generally and how people perceive themselves to be ${ }^{12}$.

Table 2 reveals the major problems the country is facing according to respondents. This is important to know the evolution of problems in Albania and point out which problems persist and which vanish over time. In 2005, 35.3 percent of the respondents said Electricity was the country's biggest problem. After 2006, this problem seems to have been solved and other issues are raised. Economic problems $^{13}$ and Unemployment have been in the top three concerns every year and have become a serious problem for people. Poverty numbers have not changed much, pointing to the fact that poverty is still a big concern. Roughly 10 percent of the respondents each year think Poverty is Albania's most important problem.

\footnotetext{
${ }^{8}$ Exchange rate in these years has fluctuated near 100 Lek/USD

${ }^{9}$ Data is taken from the 2005 Living Standards Measurement Study at http://econ.worldbank.org/WBSITE/ EXTERNAL/EXTDEC/EXTRESEARCH/EXTLSMS/0 , , contentMDK : 21369054 pagePK : 64168445 piPK : 64168309 theSitePK: $3358997,00 . \mathrm{html}$

${ }^{10}$ The Education variable in 2005 was collected as number of education years whereas later it is collected by asking respondents of the level of education they have. So data in 2005 is averaged out to be compared to the other years.

${ }^{11}$ http: //data.worldbank.org/indicator/

${ }^{12}$ In this question the answer is left to respondent's perception of their status.

${ }^{13}$ Respondents were not given options for this question so interpretations of economic problems could be many and it may very well include unemployment.
} 
Table 1: Descriptive Statistics

\begin{tabular}{|c|c|c|c|c|c|c|c|c|c|c|}
\hline & \multicolumn{2}{|c|}{ Dec-05 } & \multicolumn{2}{|c|}{ Dec-06 } & \multicolumn{2}{|c|}{ Feb-08 } & \multicolumn{2}{|c|}{ Feb-09 } & \multicolumn{2}{|c|}{ Feb-10 } \\
\hline & Mean & sd & Mean & sd & Mean & sd & Mean & $\mathrm{sd}$ & Mean & sd \\
\hline Age & 41.81 & 15.39 & 41.20 & 15.80 & 41.22 & 15.32 & 41.11 & 15.15 & 42.04 & 15.73 \\
\hline Monthly Family Income & 3.43 & 1.92 & 3.18 & 1.51 & 3.45 & 1.44 & 3.48 & 1.55 & 3.39 & 1.62 \\
\hline Ideology & 5.56 & 3.09 & 5.43 & 2.68 & 5.39 & 2.63 & 4.96 & 2.76 & 5.26 & 3.00 \\
\hline Female (pct) & 52.17 & & 52.17 & & 51.87 & & 49.08 & & 53.55 & \\
\hline No School at all (pct) & 0.67 & & 1.17 & & 1.96 & & 0.34 & & 0.24 & \\
\hline Elementary 4 Years (pct) & 4.20 & & 5.18 & & 5.01 & & 3.43 & & 3.26 & \\
\hline Elementary 8 Years (pct) & 23.17 & & 29.88 & & 27.55 & & 27.72 & & 27.23 & \\
\hline High School (pct) & 47.44 & & 47.91 & & 49.32 & & 45.90 & & 50.88 & \\
\hline University (pct) & 19.40 & & 15.69 & & 15.90 & & 21.86 & & 17.64 & \\
\hline Graduate Degree (pct) & 5.12 & & 0.17 & & 0.26 & & 0.75 & & 0.75 & \\
\hline Full time employed (pct) & 24.43 & & 21.25 & & 21.41 & & 26.39 & & 22.06 & \\
\hline Part time Employed (pct) & 3.03 & & 4.44 & & 2.67 & & 4.81 & & 5.01 & \\
\hline Self-Employed (pct) & 15.95 & & 16.89 & & 16.41 & & 13.32 & & 15.79 & \\
\hline Unemployed (pct) & 23.26 & & 25.00 & & 26.66 & & 26.05 & & 21.64 & \\
\hline Housewife (pct) & 7.05 & & 7.08 & & 9.20 & & 7.00 & & 9.86 & \\
\hline Retired (pct) & 14.95 & & 14.85 & & 14.45 & & 11.97 & & 13.28 & \\
\hline Student (pct) & 6.88 & & 8.70 & & 7.05 & & 7.76 & & 8.69 & \\
\hline Farmer (pct) & 2.94 & & 1.62 & & 0.95 & & 1.60 & & 1.50 & \\
\hline Business owner (pct) & 1.51 & & 0.17 & & 1.20 & & 1.10 & & 1.25 & \\
\hline Other (pct) & & & & & & & & & 0.92 & \\
\hline Observations & 1200 & & 1200 & & 1176 & & 1194 & & 1197 & \\
\hline
\end{tabular}

Summary statistics for the general public survey are shown. Means and standard deviations are shown by year.

Table 2: Albania's Biggest Challenges

\begin{tabular}{rrrrrr}
\hline \hline & Dec-05 & Dec-06 & Feb-08 & Feb-09 & Feb-10 \\
\hline Corruption (pct) & 5.4 & 5.1 & 5.0 & 9.2 & 7.3 \\
Economic Problems (pct) & 17.4 & 21.6 & 31.9 & 35.1 & 36.8 \\
Electricity (pct) & 35.3 & 22.8 & 2.64 & 0 & 0.92 \\
Inflation (pct) & 0.5 & 0.83 & 7.8 & 5.2 & 2.17 \\
Political Stability (pct) & 1.5 & 1.17 & 0.68 & 0.67 & 5.8 \\
Poverty (pct) & 10.3 & 7.3 & 11.4 & 11.7 & 12.4 \\
Unemployment (pct) & 16.5 & 25.7 & 32.0 & 25.2 & 27.4 \\
Other (pct) & 13.1 & 15.6 & 8.6 & 12.9 & 7.4 \\
\hline \hline
\end{tabular}

This table displays the percentage of respondents that mentioned these topics as Albania's biggest challenge. 
Table 3 presents respondents' corruption perception on various private and public institutions and their representatives through the years. They ranked the institutions in a $[1,10]$ discrete scale, where 1 refers to being "very honest" and 10 "very corrupt". Respondents think the most corrupt institutions are the Tax Collection Sector in general, Government Ministers, Doctors, Judges and Professors. The least corrupt seem to be the President, Religious Leaders, the Military, Public School Teachers ${ }^{14}$ and Media.

Table 3: Corruption Perceptions

\begin{tabular}{lccccc}
\hline \hline & $\begin{array}{c}\text { Dec-05 } \\
\text { Mean }\end{array}$ & $\begin{array}{c}\text { Dec-06 } \\
\text { Mean }\end{array}$ & $\begin{array}{c}\text { Feb-08 } \\
\text { Mean }\end{array}$ & $\begin{array}{c}\text { Feb-09 } \\
\text { Mean }\end{array}$ & $\begin{array}{c}\text { Feb-10 } \\
\text { Mean }\end{array}$ \\
\hline The President & 2.89 & 3.78 & 4.31 & 4.07 & 3.74 \\
Parliamentarians & 7.45 & 7.53 & 8.01 & 7.98 & 7.71 \\
Ministers & 7.41 & 7.41 & 7.99 & 8.10 & 7.73 \\
Mayors & 6.80 & 6.97 & 7.17 & 7.05 & 7.25 \\
Leaders of Political Parties & 7.23 & 7.52 & 7.72 & 7.45 & 7.64 \\
\hline Politicians Average & 6.40 & 6.69 & 7.03 & 6.98 & 6.79 \\
Judges & 7.46 & 7.72 & 7.72 & 7.71 & 7.69 \\
Prosecutors & 7.46 & 7.60 & 7.83 & 7.75 & 7.80 \\
\hline Judicial Sector Average & 7.47 & 7.65 & 7.77 & 7.72 & 7.74 \\
Professors & 7.11 & 7.21 & 7.22 & 6.71 & 7.42 \\
Public School Teachers & 4.80 & 4.95 & 4.77 & 4.88 & 5.15 \\
\hline Education Sector Average & 5.93 & 6.06 & 5.96 & 5.72 & 6.25 \\
Customs Officials & 8.83 & 8.69 & 8.62 & 8.59 & 8.56 \\
Tax Officials & 8.48 & 8.33 & 8.05 & 8.28 & 8.28 \\
\hline Tax Collection Sector Average & 8.65 & 8.51 & 8.33 & 8.43 & 8.41 \\
Policemen & 6.97 & 6.35 & 6.47 & 6.68 & 6.95 \\
Military & 3.84 & 4.19 & 4.19 & 4.53 & 4.07 \\
Doctors & 8.21 & 8.17 & 8.07 & 7.94 & 8.15 \\
Business People & 6.14 & 6.15 & 5.99 & 6.23 & 6.07 \\
Leaders of NGOs & 4.92 & 5.14 & 4.85 & 5.20 & 5.23 \\
Media & 4.39 & 4.78 & 4.20 & 4.42 & 4.78 \\
Religious Leaders & 3.51 & 3.83 & 3.42 & 3.44 & 3.70 \\
\hline Observations & 1200 & 1200 & 1176 & 1194 & 1197 \\
\hline \hline
\end{tabular}

Mean corruption perception indices are shown for the main political actors and institutions in Albania. They are rated on a 1 to 10 scale, where 1 refers to being "very honest" and 10 "very corrupt"

\footnotetext{
${ }^{14}$ This are teachers in the pre-university level starting from elementary school up to high school.
} 


\section{$5 \quad$ Empirical Strategy and Results}

The theoretical model suggests a few ways on how the share of population that enters into a bribe agreement (after being randomly matched) can decrease. However, enforcement increases (fines/punishment or probability of getting caught) paired with changes in quality of services can give different results theoretically too. Thus there is a need to asses this question empirically.

Assessing the economic effects of corruption, the effectiveness of enforcement mechanisms, or the success of anti-corruption efforts in general, can create a few problems. First, hard data on corrupt activities and transactions are non-existent in most cases, since corruption is an illegal activity. Second, policy variables such as law enforcement are not exogenously determined and they suffer from endogenous placement usually. Their endogeneity presents an identification problem. Despite these major difficulties, there exist answers to questions on people's direct or indirect experience with corruption and their perception on how effective the government is in fighting corruption. Moreover, in the recent years economists have made great progress in studying corruption by trying to find innovative ways to measure corruption like Reinikka and Svensson (2005) or Ferraz and Finan (2011) and see its effects in a case by case basis.

This study adds to the current within-country corruption studies by looking at the Albanian case in the 2005-2010 period. I construct a victimization index comprised of 9 binary [0,1] questions on direct experience with corruption ${ }^{15}$ based on the Albanian data for several sectors. Table 4 shows the distribution of bribes by sector for the 9 questions that comprise the victimization index. It also shows the percentage of respondents that pay at least one bribe which varies from 56.5 percent to 64.6 percent of respondents through the years.

Table 5 shows the mean victimization through the years ranging from zero to nine. The number of ways in which people are being victimized is decreasing overall, though a slight increase is observed in the most recent years. Victimization is used as a dependent variable throughout the paper. To investigate the impact of increased enforcement on bribery level changes one would need very good data on enforcement. In case good measures of enforcement exist, to test the impact of law

\footnotetext{
15 1) Did any police official ask you to pay a bribe during the last year? 2) During the last year, did any public official ask you for a bribe? 3) During the last year, to process any kind of document (like a business license), did you have to pay any money higher than prescribed by the law? 4) In order to obtain your current job; did you have to pay a bribe? 5) During the last year, did you deal with the courts? If yes, did you have to pay any bribe at the courts during the last year? 6) Did you use the public State Health Services during the last year? If yes, to be served at the State Health Service during the last year, did you have to pay any money aside of what was indicated in the receipt? 7) Did you have to pay the doctor or nurse any additional monies beyond those specified in the bill or receipt? 8) Did any of your children go to school during the last year? If yes, at the school, did they ask for any payment besides the established fees? 9) Did someone ask you for a bribe to avoid or reduce the payment of electricity, telephone, or water? Seligson (2005) also constructs a similar index.
} 
Table 4: Percentage Distribution of Bribe-Payers by Type of Bribe

\begin{tabular}{lccccc}
\hline \hline & Dec-05 & Dec-06 & Feb-08 & Feb-09 & Feb-10 \\
\hline Respondents who pay at least one Bribe (pct) & 64.6 & 56.7 & 57.7 & 55.3 & 56.5 \\
Police (pct) & 19.0 & 15.9 & 18.0 & 14.1 & 14.5 \\
Public Official (pct) & 18.8 & 15.0 & 18.6 & 10.9 & 15.2 \\
Process Documents (pct) & 45.5 & 34.0 & 44.2 & 33.0 & 34.9 \\
Obtain Job (pct) & 3.4 & 1.5 & 3.8 & 3.4 & 8.0 \\
Court (pct) & 5.0 & 4.6 & 5.2 & 4.8 & 4.0 \\
Bribe for Medical Care (pct) & 64.5 & 68.1 & 66.9 & 65.5 & 54.4 \\
Nurse or Doctor (pct) & 61.4 & 60 & 66.9 & 69.7 & 65.5 \\
School System (pct) & 20.5 & 19.0 & 12.2 & 7.0 & 16.9 \\
Electricity or Water (pct) & 11.5 & 11.5 & 13.0 & 9.2 & 9.6 \\
\hline \hline
\end{tabular}

This table shows distribution of bribes by type for those people that paid at least one type of bribe.

enforcement on the victimization index one could use the following model:

$$
V I C_{i j t}=\alpha_{1}+\beta_{1 j}+\gamma_{1 t}+\delta E_{i j t}+\psi X_{i t}+\epsilon_{i j t}
$$

where $V I C_{i t}$ denotes the victimization index for individual $i$ in cross-section $t$ and district $j, E_{i j t}$ the level of law enforcement for individual $i$ in cross-section $t$ and district $j, \beta_{1 j}$ denotes district fixed effects, $\gamma_{1 t}$ denotes year fixed effects and $X_{i t}$ additional covariates which includes Income, Ideology, Education, Occupation, etc.

Table 5: Mean Victimization

\begin{tabular}{ccccc}
\hline & Mean & sd & Min & Max \\
\hline 2005 & 1.613 & 1.623 & 0 & 9 \\
2006 & 1.300 & 1.424 & 0 & 9 \\
2008 & 1.065 & 1.222 & 0 & 9 \\
2009 & 1.204 & 1.344 & 0 & 9 \\
2010 & 1.226 & 1.381 & 0 & 9 \\
\hline
\end{tabular}

Note: Mean Victimization levels for respondents through the years. It refers to questions about their direct experience with corruption. Constructed by the author by adding the number of ways individuals are victimized.

In the above specification, potential endogeneity problems exist. In the simplest setting, considering one sector and one location and only considering the temporal variation, there could be other factors 
that can cause corruption to go down and enforcement to go up simultaneously. One scenario might be that while facing a budget crisis, the government increased the fines/punishment on corruption cases to increase the revenue accrued. Nevertheless, this does not seem plausible as the government intake of funds from prosecuting low level corruption cases (which is the focus of this study) seems negligible and there is no clear information that happened. Another possible scenario might be that with more economic growth there are more funds to be channeled to enforcement and policing which could in turn reduce bribery frequency. Looking at the problem through different sectors and regions there are other problems that could surface. For instance, in case districts with low level of enforcement are compared to those with high level of enforcement, this would lead to biased estimates. There could be an endogenous placement story suggesting that places where corruption is high have more enforcement, hence there exists an issue of misidentification. A few potential candidates that could be used as proxies for law enforcement are discussed below.

\subsection{Enforcement Variables}

The first proxy used for enforcement is respondents' answer to the question: "Do you know of any judge who has been sanctioned for not fulfilling his job correctly?". The answer is just a binary yes or no response. This variable can present endogeneity problems since those people who say that they know of judges being sanctioned might be also more exposed to bribery on average than people who respond no to the question. The second proxy is the respondent's awareness of anti-corruption initiatives. The answer again is a binary yes or no format and this variable also like any other proxy is not immune to problems of endogeneity as more aware people are maybe also more exposed or more educated. These proxies present difficulties in identifying the causal effect of enforcement on the victimization index. However, two important events occurred in 2007. First, the Parliament changed the federal law and increased the fine (incarceration time) for misuse of public office in February. Second, local elections were held in May. I exploit these two changes to solve the potential endogeneity problems in the above mentioned proxies.

\subsection{District Variation and Fine increase}

The fine increase in the anti-corruption law occurred in February 2007. This was an increase in the federal fine in one of the main laws against misuse or abuse of public office. The punishment for misuse of public office before the change was incarceration from 6 months to 5 years and up to $\$ 10,000$ fine ${ }^{16}$. The amendment of the law increased the incarceration time to "up to 7 years" and it was made specific that this is the fine in case the abuse of public office is not causing any

\footnotetext{
${ }^{16}$ In Albania, mean monthly income was $\$ 264$ in 2010 according to the Albanian Institute of Statistics.
} 
other criminal offense. In case other laws are broken, the punishment could be much higher. Given that the increase in the fine was federal, identifying its effect on the victimization index (number of bribery occurrences) can be challenging. Suppose that higher fines are correlated with lower levels of victimization. The endogeneity story implies that a decrease in victimization causes fines to increase because of the simultaneity problem. However, this story does not seem plausible.

I explore the variation of enforcement between left-governed districts and right-governed districts when the fine increases. Left-governed districts are those districts where the left coalition led by the Socialist Party(SP) won the local elections and right-governed districts refers to districts where the right coalition led by the Democratic Party(DP) won ${ }^{17}$. Specifically I compare districts that were governed by the left and remained such after the local elections with right districts before and after the elections. These districts are left and right strongholds and they will be affected systematically differently from the increase in the fine. There are several reasons why the left districts enforce more than the right districts. First, while the right (DP) controls the Central Government, districts that are governed by the left locally have incentives to enforce more, as more enforcement is a way to show their disagreement against the central government. In fact there have been cases of this type of friction between local and central governments. During this period, the leader of SP, Edi Rama was also Mayor of Tirana, the capital city. There have been many documented clashes between him as Mayor and the central government on many local projects ${ }^{18}$. Second, political platforms of the party governing the district can influence the level of enforcement. The left Socialist Party is generally more pro-poor than the right. For example, the left favors a progressive $\operatorname{tax}^{19}$ as compared to the flat tax Albania had during this period instituted by the right.

In order to check whether corruption is a bigger problem for poor people, I refer back to Table 2 at those people that say corruption is Albania's most important problem to deal with, and see how they are distributed by income. Figure 4 shows that corruption seems to be a problem predominantly for poorer and middle income people ${ }^{20}$. The biggest share of people, 42.2 percent of those that think corruption is Albania's biggest problem, fall into category four, with an income of 20,001-50,000 Lek or approximately $\$ 200-500$. It then becomes less of problem as people get richer. As a result, this suggests that the left as more liberal and with more pro-poor policies, will take the new law in place and enforce much more, whereas in right strongholds the new increase in the fine will not have any substantial changing effect.

\footnotetext{
${ }^{17}$ It should be noted that the same political parties compete in the central and local elections and these two parties are the main ones that have been in power in 22 years of democracy after communism

${ }^{18}$ http://www.gazeta55.al/gazeta/02.04.2010.pdf The prime minister saying he will block Tirana city center development project led by the Mayor of Tirana, leader of the opposition at the same time.

${ }^{19}$ It is often referred to as "honest taxation" by them http://www.ps.al/programi/

${ }^{20} 0$ - No income; 1 - Less than 10,000; 2 - 10,001-15,000; 3 - 15,001-20,000; 4 - 20,001-50,000; 5 - 50,001-80,000; 6 80,001-100,000; 7 - 100,001-150,000; 8 - 150,001-200,000; 9 - 200,001-300,000; 10 - More than 300,000.
} 
Figure 4: Corruption a bigger concern for the poor?

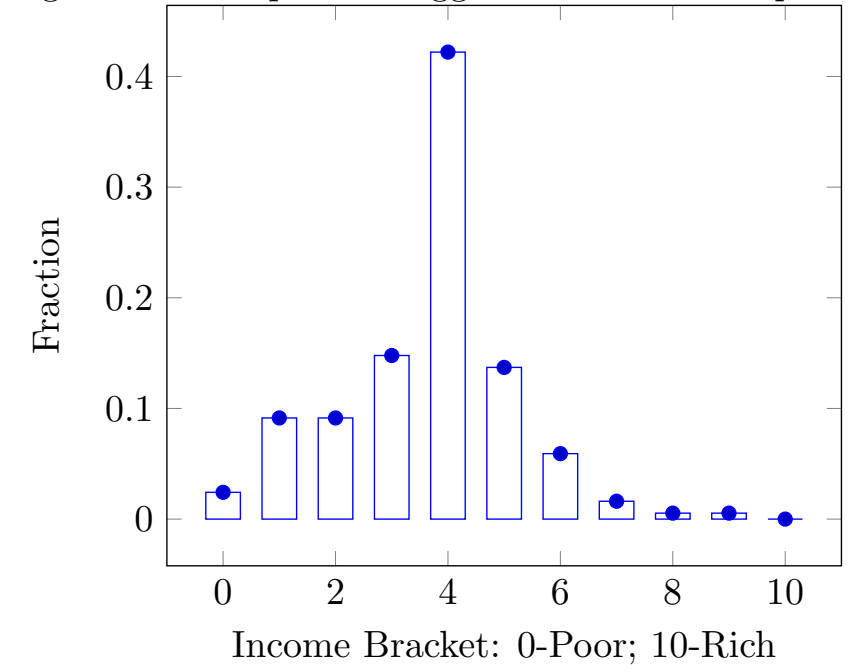

Figure 5 shows ideological distribution of individuals who claim corruptions is Albania's main problem. It shows that the majority of people that think corruption is a big problem are left leaning. Given that those that answer 1-5 are left leaning people and 6-10 are right leaning people, 63.1 percent of people that say corruption is Albania's bigger problem lean to the left. Figures 4 and 5 provide some intuition of the results that come next.

Figure 5: Corruption a bigger concern for the left supporters?

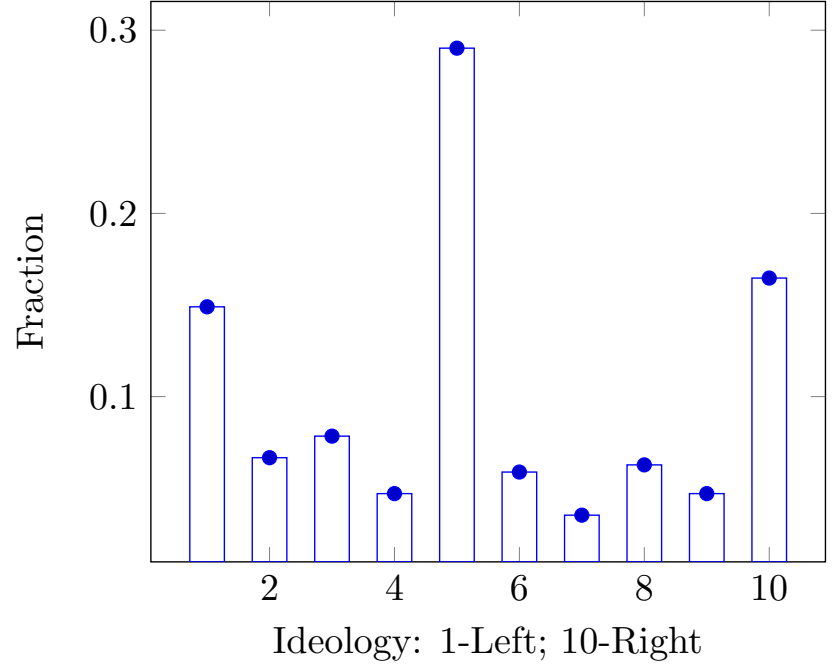

\subsubsection{Judges' Sanctions as Proxy for Enforcement}

Table 6 illustrates the identification strategy. It displays means of Enforcement(Judges' Sanctions) and Victimization for districts that are governed by left or right both before and after the local 
elections in 2007. In columns 1-3, right districts seem to enforce more initially but once the new law is introduced, left districts double their enforcement. The difference in these differences can be interpreted as the casual effect of the increase in the fine. This would work under the assumption that in the absence of the new law, enforcement trends would not have been different in left and right-governed districts.

The judges' sanctions proxy has a mean of 0.108 and standard deviation of 0.311 before the new law came in place. This means that before the increase in fine, on average 10.8 percent of people said they were aware of judges being sanctioned. According to Table 6, districts governed by the Left see an increase in enforcement on average of 6.3 percentage points more after the fine increase, which is an increase of roughly 58 percent on the mean enforcement level of pre-fine increase.

Table 6: Means of Enforcement and Victimization by District

\begin{tabular}{lcccccc}
\hline & \multicolumn{1}{c}{ Enforcement (Judges' Sanctions) } & \multicolumn{3}{c}{ Victimization } \\
\hline \multirow{4}{*}{ Left } & Right & Difference & Left & Right & Difference \\
& $(1)$ & $(2)$ & $(3)$ & $(4)$ & $(5)$ & $(6)$ \\
\hline Before & 0.103 & 0.127 & -0.025 & 1.324 & 1.210 & 0.114 \\
& $(0.0991)$ & $(0.0210)$ & $(0.0220)$ & $(0.0465)$ & $(0.0878)$ & $(0.1009)$ \\
After & 0.210 & 0.172 & 0.038 & 1.176 & 1.136 & 0.040 \\
& $(0.0080)$ & $(0.0123)$ & $(0.0152)$ & $(0.02550)$ & $(0.0440)$ & $(0.0500)$ \\
& & & & & & \\
Difference & 0.108 & 0.045 & 0.063 & -0.148 & -0.074 & -0.074 \\
& $(0.0145)$ & $(0.0262)$ & $(0.0305)$ & $(0.0507)$ & $(0.0860)$ & $(0.1082)$ \\
\hline
\end{tabular}

Note: Standard errors are in parentheses.

Columns 4-6 show the effect of increased enforcement on the Victimization index. The Victimization index ranges from 0-9 and has a mean of 1.3 and standard deviation of 1.424 before the increase in the fine. Individuals were victimized (were asked to pay bribes, or did in fact pay bribes) in 1.3 ways out of 9 possible ways before the increase in the fine. Table 6 shows that people in left districts after the increase in the fine were victimized in 0.074 ways less. This corresponds to a 5.7 percent drop in Victimization. The Wald estimate of the effect of enforcement to Victimization is the ratio of these two estimates $(0.063 /(-0.074))$. The difference in difference estimator is significantly different from zero for Enforcement, but it is not for Victimization. The remainder of the paper extends on this strategy to produce compelling results.

The identification strategy can be implemented in a regression setting by exploiting variation in left and right districts with time variation before and after the fine increase. If the fine increase leads to 
the left enforcing more, that suggests running a regression similar to Equation 5.2:

$$
E_{i j t}=\alpha_{1}+\beta_{1 j}+\gamma_{1 t}+\delta \text { Post }_{t} * \text { Left }_{j}+\psi X_{i t}++\epsilon_{i j t}
$$

where $E_{i j t}$ is a binary variable showing enforcement levels ${ }^{21}$ for person $i$ in district $j$ at time $t, \beta_{1 j}$ incorporates district fixed effects, $\gamma_{1 t}$ denotes year fixed effects, $X_{i t}$ includes individual characteristics, Post $_{t}$ is a dummy variable equal to 1 after the fine increase and $L e f t_{j}$ is a dummy equal to 1 for districts that are left strongholds before and after the elections. Post $t_{t}$ Left $_{j}$ is the variable of interest which shows the effect of the increase in fine in enforcement levels. Table 7 (columns 1-3) shows results of estimating equation 5.2. The variable of interest is Post $*$ Left which is significant in all specifications and positive. Enforcement levels increase by 50.9 percent $(0.055 / 0.108)$ in left districts after the fine increase.

Table 7: First Stage and Reduced Form, Judges' Sanctions

\begin{tabular}{|c|c|c|c|c|c|c|}
\hline & \multicolumn{6}{|c|}{ Dependent Variable } \\
\hline & \multicolumn{3}{|c|}{ Judges' Sanctions } & \multicolumn{3}{|c|}{ Victimization } \\
\hline & (1) & $(2)$ & $(3)$ & (4) & $(5)$ & $(6)$ \\
\hline \multirow[t]{2}{*}{ Ideology } & -0.0022 & -0.0019 & -0.0019 & $-0.040^{* * *}$ & $-0.038^{* * *}$ & $-0.037^{* * *}$ \\
\hline & $(0.0026)$ & $(0.0025)$ & $(0.0025)$ & $(0.0091)$ & $(0.0091)$ & $(0.0091)$ \\
\hline \multirow[t]{2}{*}{ Education } & $0.029^{* * *}$ & $0.029^{* * *}$ & $0.026^{* * *}$ & & & \\
\hline & $(0.0085)$ & $(0.0085)$ & $(0.0084)$ & & & \\
\hline \multirow[t]{2}{*}{ Post*Left } & $0.064^{* * *}$ & $0.11^{* * *}$ & $0.055^{* *}$ & 0.0016 & $-0.18^{* * *}$ & $-0.29^{* * *}$ \\
\hline & $(0.014)$ & $(0.016)$ & $(0.035)$ & $(0.050)$ & $(0.060)$ & $(0.091)$ \\
\hline \multirow[t]{2}{*}{ Constant } & $0.080^{* * *}$ & $-0.063^{* *}$ & $-0.077^{*}$ & $1.45^{* * *}$ & $1.42^{* * *}$ & $1.35^{* * *}$ \\
\hline & $(0.030)$ & $(0.032)$ & $(0.045)$ & $(0.068)$ & $(0.078)$ & $(0.083)$ \\
\hline Year Fixed Effects & No & No & Yes & No & No & Yes \\
\hline District Fixed Effects & No & Yes & Yes & No & Yes & Yes \\
\hline Observations & 2982 & 2982 & 2982 & 3029 & 3029 & 3029 \\
\hline
\end{tabular}

Note: Standard errors are in parentheses, ${ }^{*} p<0.10,{ }^{* *} p<0.05,{ }^{* * *} p<0.01$

The same identification strategy could be applied to find the effect of the fine increase on Victimization estimating this equation:

$$
V I C_{i j t}=\alpha_{1}+\beta_{1 j}+\gamma_{1 t}+\delta \text { Post }_{t} * \text { Left }_{j}+\psi X_{i t}++\epsilon_{i j t}
$$

where $V I C_{i j t}$ is the Victimization of person $\mathrm{i}$ in district $\mathrm{j}$ in period t. Columns 4-6 in Table 7 show that Victimization drops by 0.22 units in Left governed districts after the fine increase. This

\footnotetext{
${ }^{21}$ I use as a proxy, individual's answer to the question: Do you know of any judge who has been sanctioned for not fulfilling his job correctly?.
} 
corresponds to a 22.3 percent drop in Victimization since the average before the increase in the fine was 1.3 .

All the estimations rest on the parallel trend assumption, that in the absence of the fine increase, bribery (measured by Victimization) trend evolution would not have been different between left and right-governed districts. If on the other hand we assume that the increase in the fine had no effect on Victimization other than through enforcement, then we can instrument for enforcement and use a 2SLS regression to estimate the impact of enforcement on Victimization. If we estimate an equation like 5.1, estimates may be biased in case there is a correlation between Enforcement and the errors. As a result, I instrument for enforcement with the interaction term Post $_{t} *$ Left $_{j}$. Table 8 shows 2 SLS estimations. Results show that when enforcement level goes from 0 to 1 (proxied as before with the respondents' answer on judges being sanctioned), Victimization drops by 2.88 units out of 9 ways in which people get victimized through bribery. Since enforcement does not go up from zero to one, but from 0.108 to 0.171 , victimization drops by 0.18 units $\left(2.88^{*} 0.063\right)$ or 13.8 percent.

Table 8: 2SLS, Judges' Sanctions

\begin{tabular}{lcc}
\hline & \multicolumn{2}{c}{ Dependent Variable } \\
\cline { 2 - 3 } & \multicolumn{2}{c}{ Victimization } \\
\cline { 2 - 3 } & $(1)$ & $(2)$ \\
\hline Judges' Sanctions & $-2.88^{*}$ & $-1.57^{* *}$ \\
& $(1.66)$ & $(0.77)$ \\
Constant & $1.72^{* * *}$ & $1.90^{* * *}$ \\
& $(0.17)$ & $(0.34)$ \\
\hline Control Variables & No & Yes \\
Year Fixed Effects & Yes & Yes \\
District Fixed Effects & Yes & Yes \\
\hline Observations & 3255 & 2854 \\
\hline Note: Controls include Ideology, Education and Occu- \\
pation. Standard errors are in parentheses, ${ }^{*} p<0.10$, \\
$* * p<0.05,{ }^{* * *} p<0.01$
\end{tabular}

\subsubsection{Awareness on Anti-Corruption as Proxy for Enforcement}

I use below the respondents' awareness on anti-corruption initiatives, instead of using judges' sanctions as a proxy for enforcement to see if the results hold. Awareness has a mean of 0.396 (39.6 percent of people surveyed say they are aware of anti corruption initiatives) and standard deviation of 0.489 . Table 9 shows first stage regression results where in Left districts after the 
fine increase, enforcement goes up by 0.22 units in column 3, which corresponds to a 55.5 percent increase(0.22/0.396). Table 10 shows 2SLS results. When respondents' answer goes from 0 to 1 , Victimization drops by 1.20 units out of 9 ways in which people can get victimized by paying a bribe or by 26.4 percent $(0.22 * 1.2)$.

Table 9: First Stage, Awareness

\begin{tabular}{lccc}
\hline & \multicolumn{3}{c}{ Dependent Variable } \\
\cline { 2 - 4 } & \multicolumn{3}{c}{ Awareness } \\
\cline { 2 - 4 } & $(1)$ & $(2)$ & $(3)$ \\
\hline Ideology & $0.0099^{* *}$ & $.0121^{* * *}$ & $0.0096^{* *}$ \\
Education & $(0.0047)$ & $(.0029)$ & $(0.0047)$ \\
& $0.11^{* * *}$ & $0.11^{* * *}$ & $0.11^{* * *}$ \\
Post*Left & $(0.015)$ & $(0.014)$ & $(0.015)$ \\
& 0.013 & $0.046^{*}$ & $0.22^{* * *}$ \\
Constant & $(0.026)$ & $(0.027)$ & $(0.056)$ \\
& $0.093^{*}$ & $0.20^{* * *}$ & $-0.45^{* * *}$ \\
\hline Year Fixed Effects & $(0.050)$ & $(0.045)$ & $(0.13)$ \\
District Fixed Effects & No & No & Yes \\
\hline Observations & 1516 & 1650 & Yes \\
\hline Note: Standard errors are in parentheses, ${ }^{*} p<0.10,{ }^{* *} p<0.05$, \\
*** $p<0.01$
\end{tabular}

\subsection{Quality of Services}

Theory suggests that when enforcement increases, quality of services could increase or decrease. Getting a certificate might have taken two hours when customers were paying bribes before the increased enforcement, but it might take them six hours after the increase in enforcement because of longer lines or other similar reasons. On the other hand, before the enforcement went up, public officials might have made people wait a long time to extract bribes from them. After enforcement increases, there is no point anymore in prolonging procedures. Table 11 shows the reduced form regressions of the impact of increased enforcement on several variables linked to quality of services. The same identification strategy is followed. Respondents were asked how they were treated by the Police, at the Courts, Prosecutor's office and Municipalities. Their answer varied from 1-4 discretely with four being the best treatment. People were treated more poorly and quality of services decreased slightly in left districts. For instance, the courts got in 2006 an average score of 2.43 , while after the fine increase average treatment of people by the courts dropped by 0.17 units or 6.9 percent respectively. 
Table 10: 2SLS, Awareness

\begin{tabular}{lcc}
\hline & \multicolumn{2}{c}{ Dependent Variable } \\
\cline { 2 - 3 } & \multicolumn{2}{c}{ Victimization } \\
\cline { 2 - 3 } & $(1)$ & $(2)$ \\
\hline Awareness & $-1.59^{*}$ & $-1.58^{*}$ \\
& $(0.91)$ & $(0.84)$ \\
Constant & $2.12^{* * *}$ & $1.52^{* * *}$ \\
& $(0.48)$ & $(0.29)$ \\
\hline Control Variables & No & Yes \\
Year Fixed Effects & Yes & Yes \\
District Fixed Effects & Yes & Yes \\
\hline Observations & 1651 & 1650 \\
\hline
\end{tabular}

Note: Controls include Ideology, Education and Occupation.

Standard errors are in parentheses, ${ }^{*} p<0.10,{ }^{* *} p<0.05$, *** $p<0.01$

Table 11: General Public Treatment

\begin{tabular}{lcccc}
\hline & \multicolumn{4}{c}{ Dependent Variable } \\
\cline { 2 - 5 } & Police & Courts & $\begin{array}{c}\text { Prosecutor's } \\
\text { Office }\end{array}$ & Municipality \\
\cline { 2 - 5 } & $(1)$ & $(2)$ & $(3)$ & $(4)$ \\
\hline Ideology & $0.032^{* * *}$ & $0.026^{* *}$ & $0.028^{*}$ & 0.0058 \\
& $(0.0097)$ & $(0.012)$ & $(0.015)$ & $(0.0063)$ \\
Post*Left & -0.063 & $-0.17^{* *}$ & $-0.29^{* *}$ & $-0.084^{* *}$ \\
& $(0.093)$ & $(0.079)$ & $(0.14)$ & $(0.042)$ \\
\hline Year Fixed Effects & Yes & Yes & Yes & Yes \\
District Fixed Effects & Yes & Yes & Yes & Yes \\
\hline Observations & 785 & 492 & 346 & 1357 \\
\hline
\end{tabular}

Note: Standard errors are in parentheses, ${ }^{*} p<0.10,{ }^{* *} p<0.05,{ }^{* * *} p<0.01$ 


\subsection{Sectoral Variation}

There might be differences in the implementation of the law in different sectors. One hypothesis could be that the fine increase did not affect much bribery on the medical and education sector as it might have affected other sectors. In these two sectors there is a need to maintain a relationship with the doctor or teacher so the increase in the fine might not have had any significant effect. Consumers are also more willing to bribe for medical assistance or education purposes because it affects their livelihood and their future in a more direct way. In other sectors, the increase in the fine might produce a decrease in the victimization level since the service provided might not be that important for citizens and it is mostly a one shot game. Officials might be more scared to ask for bribes knowing this could increase the likelihood of bribe reporting. Referring back to Table 4, more than 60 percent of the people who pay bribes, pay them to doctors or nurses in the medical sector. In the latter years, even though less people bribe as a percentage of respondents, the share of people paying bribes in the medical sector does not decrease, except for 2010. As a result, the decrease in bribery must have come from different sectors such as bribes paid to a police official, administrative bribes to process documents or bribes paid in the school system. This seems to corroborate the assumption that the fine increase is not likely to have affected the medical sector right after the law change in 2007. According to a study done by UNODC (2011), 71 percent of citizens who pay bribes pay them to doctors and 47 percent to nurses ${ }^{22}$. This makes sense since 70 percent of respondents in this study say the bribe payments are made to receive better treatment.

To investigate this, I pursue a difference in difference approach for the medical and education sector compared to other sectors in the equation below:

$$
V I C_{i t}=\alpha_{1}+\gamma_{1 t}+\beta \text { NonMedEduc } i+\delta \text { Post }_{t} * \text { NonMedEduc } i+\psi X_{i t}+\epsilon_{i t}
$$

where $V I C_{i t}$ denotes Victimization level for person $i$ at time $t, N_{\text {on }} M e d E d u c_{i}$ is a dummy equal to 1 if person i did not have contact with the Medical sector or the Education sector, $\gamma_{1 t}$ denotes year fixed effects, $X_{i t}$ includes individual characteristics. The coefficient of interest now is $\delta$, which shows the effect of the increase of the fine in the non-medical and education sectors. Table 12 shows that in the sectors different from the medical and education sector taken together, people were victimized in 1.05 ways less than in those two sectors comparatively. The average victimization in the education and medical sector together before the fine increase was 1.47. As a consequence, there is a huge disparity between these two groups.

\footnotetext{
${ }^{22}$ The sum in this study and in Table 4 adds up to more than 100 percent because bribe-payers have made payments to more than one public official in one year
} 
Table 12: Sectoral Variation

\begin{tabular}{lccc}
\hline & \multicolumn{3}{c}{ Dependent Variable } \\
\cline { 2 - 4 } & \multicolumn{3}{c}{ Victimization } \\
\cline { 2 - 4 } & $(1)$ & $(2)$ & $(3)$ \\
\hline NonMedEduc & $(0.039)$ & $(0.041)$ & $(0.045)$ \\
Ideology & $-0.039^{* * *}$ & $-0.037^{* * *}$ & $-0.035^{* * *}$ \\
& $(0.0084)$ & $(0.0085)$ & $(0.0085)$ \\
Constant & $1.45^{* * *}$ & $1.54^{* * *}$ & $1.35^{* * *}$ \\
& $(0.027)$ & $(0.067)$ & $(0.079)$ \\
\hline Year Fixed Effects & No & No & Yes \\
District Fixed Effects & No & Yes & Yes \\
\hline Observations & 3118 & 3118 & 3118 \\
\hline Note: Standard errors are in parentheses, * $p<0.10, * *$ & $<<0.05, * * *$ \\
$p<0.01$ & & & \\
& & & $-1.09^{* * *}$ \\
& & &
\end{tabular}

\section{Robustness Checks}

In tables 13 through 16, "the treatment" group is now considered to be those districts that shifted in the local elections from Right to Left. All the other districts will be part of the control group. Results have the same sign and are significant. 
Table 13: First Stage and Reduced Form, Judges'Sanctions

\begin{tabular}{|c|c|c|c|c|c|c|}
\hline & \multicolumn{6}{|c|}{ Dependent Variable } \\
\hline & \multicolumn{3}{|c|}{ Judges' Sanctions } & \multicolumn{3}{|c|}{ Victimization } \\
\hline & (1) & $(2)$ & (3) & (4) & $(5)$ & (6) \\
\hline \multirow[t]{2}{*}{ Ideology } & -0.0024 & -0.0023 & -0.0019 & $-0.027^{* * *}$ & $-0.037^{* * *}$ & $-0.036^{* * *}$ \\
\hline & $(0.0022)$ & $(0.0021)$ & $(0.0021)$ & $(0.0070)$ & $(0.0074)$ & $(0.0074)$ \\
\hline \multirow[t]{2}{*}{ Education } & $0.024^{* * *}$ & $0.024^{* * *}$ & $0.020^{* * *}$ & & & \\
\hline & $(0.0071)$ & $(0.0071)$ & $(0.0070)$ & & & \\
\hline \multirow[t]{2}{*}{ Post*Left } & -0.0086 & $0.093^{* * *}$ & -0.0099 & $-0.20^{* * *}$ & $-0.30^{* * *}$ & $-0.24^{* *}$ \\
\hline & $(0.018)$ & $(0.025)$ & $(0.029)$ & $(0.058)$ & $(0.089)$ & $(0.092)$ \\
\hline \multirow[t]{2}{*}{ Constant } & $0.13^{* * *}$ & $-0.046^{*}$ & $-0.17^{* * *}$ & $1.46^{* * *}$ & $1.35^{* * *}$ & $1.43^{* * *}$ \\
\hline & $(0.024)$ & $(0.026)$ & $(0.031)$ & $(0.043)$ & $(0.055)$ & $(0.067)$ \\
\hline Year Fixed Effects & No & No & Yes & No & No & Yes \\
\hline District Fixed Effects & No & Yes & Yes & No & Yes & Yes \\
\hline Observations & 4322 & 4322 & 4322 & 5505 & 4382 & 4382 \\
\hline
\end{tabular}

Note: Standard errors are in parentheses, ${ }^{*} p<0.10,{ }^{* *} p<0.05,{ }^{* * *} p<0.01$

Table 14: 2SLS, Judges' Sanctions

\begin{tabular}{lcc}
\hline & \multicolumn{2}{c}{ Dependent Variable } \\
\cline { 2 - 3 } & \multicolumn{2}{c}{ Victimization } \\
\cline { 2 - 3 } & $(1)$ & $(2)$ \\
\hline Judges' Sanctions & $-3.22^{*}$ & $-2.83^{*}$ \\
& $(1.86)$ & $(1.64)$ \\
Constant & $1.61^{* * *}$ & $1.50^{* * *}$ \\
& $(0.31)$ & $(0.27)$ \\
\hline Control Variables & No & Yes \\
Year Fixed Effects & Yes & Yes \\
District Fixed Effects & Yes & Yes \\
\hline Observations & 4703 & 4702 \\
\hline
\end{tabular}

Note: Controls include Ideology, Education and Occupation. Standard errors are in parentheses, ${ }^{*} p<0.10$, ** $p<0.05,{ }^{* * *} p<0.01$ 
Table 15: First Stage, Awareness

\begin{tabular}{lccc}
\hline & \multicolumn{3}{c}{ Dependent Variable } \\
\cline { 2 - 4 } & \multicolumn{3}{c}{ Awareness } \\
\cline { 2 - 4 } & $0.0088^{* *}$ & $0.0083^{* *}$ & $0.0083^{* *}$ \\
& $(0.0039)$ & $(0.0039)$ & $(0.0039)$ \\
Ideology & $0.12^{* * *}$ & $0.11^{* * *}$ & $0.11^{* * *}$ \\
Education & $(0.012)$ & $(0.012)$ & $(0.012)$ \\
& -0.038 & $0.13^{* * *}$ & $0.15^{* * *}$ \\
Post*Left & $(0.037)$ & $(0.046)$ & $(0.052)$ \\
Constant & 0.047 & 0.067 & 0.047 \\
& $(0.039)$ & $(0.14)$ & $(0.15)$ \\
\hline Year Fixed Effects & No & No & Yes \\
District Fixed Effects & No & Yes & Yes \\
\hline Observations & 2168 & 2168 & 2168 \\
\hline Note: Standard errors are in parentheses, ${ }^{*} p<0.10,{ }^{* *} p<0.05, * * *$ \\
$p<0.01$
\end{tabular}

Table 16: 2SLS, Awareness

\begin{tabular}{lcc}
\hline & \multicolumn{2}{c}{ Dependent Variable } \\
\cline { 2 - 3 } & \multicolumn{2}{c}{ Victimization } \\
\cline { 2 - 3 } & $(1)$ & $(2)$ \\
\hline Awareness & -2.83 & $-2.80^{* *}$ \\
& $(1.74)$ & $(1.41)$ \\
Constant & $2.77^{* * *}$ & $2.06^{* * *}$ \\
& $(0.81)$ & $(0.34)$ \\
\hline Control Variables & No & Yes \\
Year Fixed Effects & Yes & Yes \\
District Fixed Effects & Yes & Yes \\
\hline Observations & 2339 & 2077 \\
\hline
\end{tabular}

Note: Controls include Ideology, Education and Occupation. Standard errors are in parentheses, ${ }^{*} p<0.10,{ }^{* *} p<0.05$, *** $p<0.01$ 
In tables 17 through 20, I compare districts that end up Left after the elections with districts that end up Right. Results are consistent even in this case.

Table 17: First Stage and Reduced Form, Judges'Sanctions

\begin{tabular}{|c|c|c|c|c|c|c|}
\hline & \multicolumn{6}{|c|}{ Dependent Variable } \\
\hline & \multicolumn{3}{|c|}{ Judges' Sanctions } & \multicolumn{3}{|c|}{ Victimization } \\
\hline & (1) & $(2)$ & (3) & (4) & $(5)$ & (6) \\
\hline \multirow[t]{2}{*}{ Ideology } & -0.0019 & -0.0019 & -0.0019 & $-0.028^{* * *}$ & $-0.037^{* * *}$ & $-0.036^{* * *}$ \\
\hline & $(0.0021)$ & $(0.0021)$ & $(0.0021)$ & $(0.0069)$ & $(0.0074)$ & $(0.0074)$ \\
\hline \multirow[t]{2}{*}{ Education } & $0.022^{* * *}$ & $0.022^{* * *}$ & $0.020^{* * *}$ & & & \\
\hline & $(0.0071)$ & $(0.0071)$ & $(0.0070)$ & & & \\
\hline \multirow[t]{2}{*}{ Post*Left } & $0.075^{* * *}$ & $0.12^{* * *}$ & $0.052^{*}$ & $-0.25^{* * *}$ & $-0.22^{* * *}$ & $-0.24^{* * *}$ \\
\hline & $(0.012)$ & $(0.014)$ & $(0.027)$ & $(0.038)$ & $(0.049)$ & $(0.070)$ \\
\hline \multirow[t]{2}{*}{ Constant } & $0.090^{* * *}$ & $-0.17^{* * *}$ & $-0.10^{* * *}$ & $1.55^{* * *}$ & $1.40^{* * *}$ & $1.39^{* * *}$ \\
\hline & $(0.024)$ & $(0.028)$ & $(0.038)$ & $(0.046)$ & $(0.058)$ & $(0.067)$ \\
\hline Year Fixed Effects & No & No & Yes & No & No & Yes \\
\hline District Fixed Effects & No & Yes & Yes & No & Yes & Yes \\
\hline Observations & 4322 & 4322 & 4322 & 5505 & 4382 & 4382 \\
\hline
\end{tabular}

Note: Standard errors are in parentheses, ${ }^{*} p<0.10,{ }^{* *} p<0.05,{ }^{* * *} p<0.01$ 
Table 18: 2SLS, Judges' Sanctions

\begin{tabular}{lcc}
\hline & \multicolumn{2}{c}{ Dependent Variable } \\
\cline { 2 - 3 } & \multicolumn{2}{c}{ Victimization } \\
\cline { 2 - 3 } & $(1)$ & $(2)$ \\
\hline \multirow{2}{*}{ Judges' Sanctions } & $-2.03^{*}$ & $-1.96^{*}$ \\
& $(1.16)$ & $(1.14)$ \\
Constant & $1.65^{* * *}$ & $1.54^{* * *}$ \\
& $(0.14)$ & $(0.22)$ \\
\hline Control Variables & No & Yes \\
Year Fixed Effects & Yes & Yes \\
District Fixed Effects & Yes & Yes \\
\hline Observations & 4703 & 4142 \\
\hline
\end{tabular}

Note: Controls include Ideology and Occupation. Standard errors are in parentheses, ${ }^{*} p<0.10,{ }^{* *} p<0.05$, *** $p<0.01$

Table 19: First Stage, Awareness of Anti-corruption Initiatives

\begin{tabular}{|c|c|c|c|}
\hline & \multicolumn{3}{|c|}{ Dependent Variable } \\
\hline & \multicolumn{3}{|c|}{ Awareness } \\
\hline & (1) & $(2)$ & (3) \\
\hline \multirow[t]{2}{*}{ Ideology } & $0.0089^{* *}$ & $0.0082^{* *}$ & $0.0078^{* *}$ \\
\hline & $(0.0039)$ & $(0.0039)$ & $(0.0039)$ \\
\hline \multirow[t]{2}{*}{ Education } & $0.12^{* * *}$ & $0.11^{* * *}$ & $0.11^{* * *}$ \\
\hline & $(0.012)$ & $(0.012)$ & $(0.012)$ \\
\hline \multirow[t]{2}{*}{ Post*Left } & $0.043^{* *}$ & $0.062^{* * *}$ & $0.21^{* * *}$ \\
\hline & $(0.022)$ & $(0.024)$ & $(0.046)$ \\
\hline \multirow[t]{2}{*}{ Constant } & 0.028 & 0.066 & -0.082 \\
\hline & $(0.039)$ & $(0.14)$ & $(0.15)$ \\
\hline Year Fixed Effects & No & No & Yes \\
\hline District Fixed Effects & No & Yes & Yes \\
\hline Observations & 2168 & 2168 & 2168 \\
\hline
\end{tabular}


Table 20: 2SLS Results, Awareness

\begin{tabular}{lcc}
\hline & \multicolumn{2}{c}{ Dependent Variable } \\
\cline { 2 - 3 } & \multicolumn{2}{c}{ Victimization } \\
\cline { 2 - 3 } & $(1)$ & $(2)$ \\
\hline Awareness & $-1.20^{* *}$ & $-1.12^{*}$ \\
& $(0.57)$ & $(0.59)$ \\
Constant & $2.01^{* * *}$ & $1.72^{* * *}$ \\
& $(0.27)$ & $(0.19)$ \\
\hline Control Variables & No & Yes \\
Year Fixed Effects & Yes & Yes \\
District Fixed Effects & Yes & Yes \\
\hline Observations & 2339 & 2077 \\
\hline
\end{tabular}

Note: Controls include Ideology, Education and Occupation. Standard errors are in parentheses, ${ }^{*} p<0.10$, ${ }^{* *} p<0.05,{ }^{* * *} p<0.01$

\section{Conclusion}

This paper addresses the impact of increased law enforcement on the number of bribes in public service delivery sector. I model the flow of events in the consumer - public official relationship. Once people are randomly matched with public officials, there may exist a bribe level that could be beneficial to both parties. By defining the share of population that gets involved in a bribe agreement, I show theoretically how law enforcement can impact the level of bribery. Theory suggests that as enforcement increases, bribery occurrence can increase or decrease. To look at this empirically, I study the effect of a fine increase on corrupt behavior on the victimization index. I instrument imperfect and endogenous measures of enforcement like judges sanctions and awareness of anti-corruption initiatives with the interaction of the post treatment dummy with left strongholds local governments.

An increase in enforcement reduces bribery frequency significantly. Results are robust to different variations of Left and Right governed districts. However, quality of services decreases during this time. I investigate through a difference in difference estimation technique whether the fine increase has different impact in different sectors. Estimations show that the impact on the medical and education sectors has been significantly lower for these two sectors compared to the other sectors. 


\section{Bibliography}

Abbink, K., Dasgupta, U., Gangadharan, L., and Jain, T. (2012). Letting the briber go free: An experiment on mitigating harassment bribes. Working Paper.

Basu, K. (2011). Why, for a class of bribes, the act of giving a bribe should be treated as legal. Ministry of Finance Working Paper.

Becker, G. and Stigler, G. (1974). Law enforcement, malfeasance and the compensation of enforcers. Journal of Legal Studies, 3(1):1-19.

Ferraz, C. and Finan, F. (2011). Electoral accountability and corruption: Evidence from the audits of local governments. American Economic Review, 104:1274-1311.

Fisman, R. and Miguel, E. (2007). Corruption, norms, and legal enforcement: Evidence from diplomatic parking tickets. Journal of Political Economy, 115(6):795-813.

IDRA (2010). Corruption in albania, perception and experiences. Institute for Development Research and Alternatives.

McMillan, J. and Zoido, P. (2004). How to subvert democracy: Montesinos in peru. Journal of Economic Prespectives, 18(4):69-92.

Olken, B. A. and Pande, R. (2011). Corruption in dveloping countries. National Bureau of Economic Research.

Polinsky, M. A. and Shavell, S. (2001). Corruption and optimal law enforcement. Journal of Public Economics, 81:1-24.

Reinikka, R. and Svensson, J. (2004). Local capture: Evidence from a central government transfer program in uganda. The Quarterly Journal of Economics, 119:679-705.

Reinikka, R. and Svensson, J. (2005). Fighting corruption to improve schooling: Evidence from a newspaper campaign in uganda. Journal of the European Economic Association, 3:259267.

Rose-Ackerman, S. (1978). Corruption: A study in political economy. New York: Academic Press.

Seligson, M. A. (2005). The measurement and impact of corruption victimization: Survey evidence from latin america. World Development, 34(2):381-404.

Thompson, T. and Shah, A. (2005). Transparency international's corruption perceptions index: Whose perceptions are they anyway. World Bank Working Paper.

UNODC (2011). Corruption in albania: Bribery as experienced by the population. United Nations Office on Drugs and Crime. 


\section{Appendix}

\subsection{Fine Incidence}

In (Basu 2011) the author advocates letting only the public official take the sanctions of a bribe exchange and considering the act of bribe giving on the consumer side as legal, but only for "harassment" bribes. His claim is that enacting this policy would immediately reduce the incidence of bribery and increase the incentive of bribe reporting. This claim doesn't mean that the act of bribe giving becomes legal, just that the punishment or sanction is shifted onto the bribe taker only. Abbink et al. (2012) set up an experiment to investigate his claim and conclude that the policy can potentially reduce bribe practices but that the incentives for the bribe giver are weak and once retaliation by the bribe-taker is accounted for, then the effect of this policy diminishes. So implementing this policy in the field would face challenges.

In the model, the extreme cases where the penalty falls only on the public official or consumer respectively the set of combinations where a bribe would take place is presented in Figure 4 and Figure 5. The equation of the line becomes $\mu_{j}=\frac{g-g^{\prime}}{f}$ in Figure 4 and $\rho_{i}=\frac{g-g^{\prime}}{F}$ in Figure 5 .

Figure 6: Fine falls on public official only

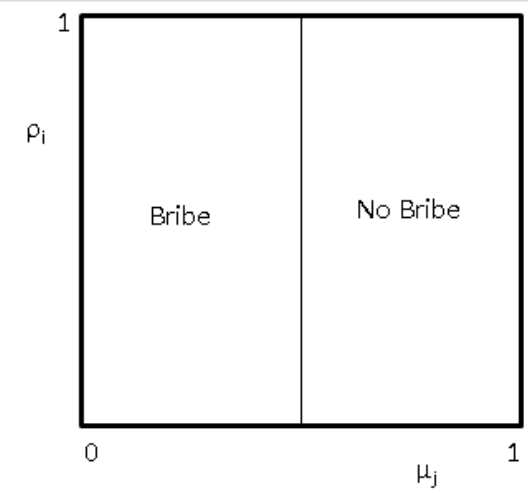

If $\mu_{j}$ and $\rho_{i}$ are uniformly distributed then the share of the population that is involved in a bribe transaction is represented by the area of the square where a bribe would take place. In the extreme case where only the official takes the penalty or only the consumer the area would be:

$$
\text { Area }= \begin{cases}\mu_{j}=\frac{g-g^{\prime}}{f} & \text { when only the public official is fined } \\ \rho_{i}=\frac{g-g^{\prime}}{F} & \text { when only the consumer is fined }\end{cases}
$$

There are four general cases of the population that engages in bribery depending on the parameters: 
Figure 7: Fine falls on the consumer only

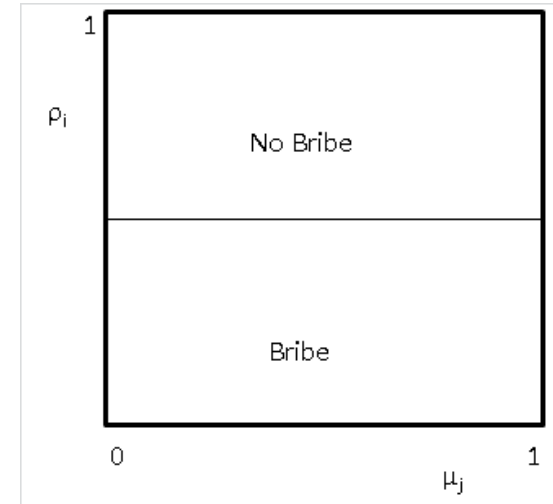

Figure 8: Different Scenarios

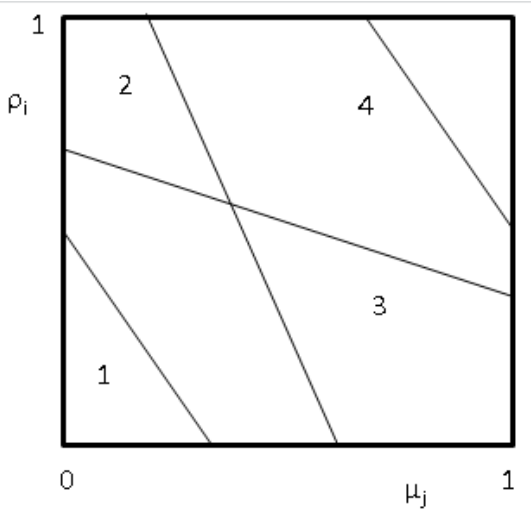

$$
\text { Area }= \begin{cases}1: \frac{\left(g-g^{\prime}\right)^{2}}{2 f F} & \text { intercepts } \mu_{j}<1, \rho_{i}<1 \\ 2: \frac{2 g-2 g^{\prime}-F}{2 f} & \text { intercepts } \mu_{j}<1, \rho_{i}=1 \\ 3: \frac{2 g-2 g^{\prime}-f}{2 F} & \text { intercepts } \mu_{j}=1, \rho_{i}<1 \\ 4: \frac{2 f F-\left(g-g^{\prime}-F\right)\left(g-g^{\prime}-f\right)}{2 f F} & \text { intercepts } \mu_{j}=1, \rho_{i}=1\end{cases}
$$

It would be interesting to compare what happens to the share of population involved in a bribe transaction when both the bribe giver and bribe taker are punished compared to when only one of them is punished. The areas above could be rewritten in this way:

$$
\text { Area }= \begin{cases}1: \frac{g-g^{\prime}}{f} \frac{g-g^{\prime}}{2 F} & \text { intercepts } \mu_{j}<1, \rho_{i}<1 \\ 2: \frac{g-g^{\prime}}{f}-\frac{F}{2 f} & \text { intercepts } \mu_{j}<1, \rho_{i}=1 \\ 3: \frac{g-g^{\prime}}{F}-\frac{f}{2 F} & \text { intercepts } \mu_{j}=1, \rho_{i}<1 \\ 4: \frac{1}{2}-\frac{g-g^{\prime}}{f} \frac{g-g^{\prime}}{2 F}-\frac{g-g^{\prime}}{f} \frac{F+f}{2 F} & \text { intercepts } \mu_{j}=1, \rho_{i}=1\end{cases}
$$

In Case 2 it is clear that the share of population that is involved in bribery decreases when only the official is punished. The same happens in case 3 when only the consumer is punished. This 
contradicts the implication of (Abbink et al. 2012).

\subsection{Income Distribution}

In order to maker sure the income distribution of this study is close to other surveys conducted in Albania, I compare income data from the survey used in this paper to the LSMS (Living Standards Measurement Survey) survey in Albania. The comparison is done for the year 2005 in both surveys, for which the latest LSMS data were available. The comparison is not complete since in the survey used in the paper respondents' answer is based on an income bracket ${ }^{23}$, whereas in LSMS households give their exact monthly income. Table 21 shows the comparison by percentiles. The two surveys are pretty close to each other so income distribution is representative in this survey compared to LSMS and does not create reasons for concern.

Table 21: Monthly Household Income Compari-

son

\begin{tabular}{lcc}
\hline \hline Percentiles & Author's survey & LSMS survey \\
\hline & & \\
$1 \%$ & No Income & 0 \\
$5 \%$ & No Income & 4,050 \\
$10 \%$ & $<10,000$ & 7,500 \\
$25 \%$ & $10,000-15,000$ & 14,000 \\
$50 \%$ & $20,000-50,000$ & 24,000 \\
$75 \%$ & $20,000-50,000$ & 40,000 \\
$90 \%$ & $50,000-80,000$ & 60,000 \\
$95 \%$ & $80,000-100,000$ & 80,000 \\
$99 \%$ & $>300,000$ & 150,000 \\
& & \\
\hline Mean & 3.434 & 37464 \\
Std. Dev. & 1.921 & 2380298 \\
Variance & 3.692 & $5.67 \mathrm{E}+12$ \\
\hline \hline
\end{tabular}

This table compares monthly household income data of the survey used in this paper to LSMS data. The comparison year is done for 2005 .

\footnotetext{
${ }^{23}$ In which income bracket does your family income fall in new Leks? 0 - No income; 1 - Less than 10,000; 2 10,001-15,000; 3 - 15,001-20,000; 4 - 20,001-50,000; 5 - 50,001-80,000; 6 - 80,001-100,000; 7 - 100,001-150,000; 8 150,001-200,000; 9 - 200,001-300,000; 10 - More than 300,000.
} 